J. Amer. Soc. Hort. Sci. 115(1):107-110. 1990.

\title{
Gibberellin Inhibits Fruit Abscission Following Seed Abortion in Peach
}

\author{
G.W. Stutte and J. Gage \\ Department of Horticulture, University of Maryland, College Park, MD 20742 \\ Additional index words. fruit set, $\mathrm{GA}_{3}, \mathrm{GA}_{4+7}$, fruit development, parthenocarpy, Prunus persica
}

\begin{abstract}
Seed coats of developing fruit of peach [Prunus persica (L.) Batsch Cvs. Redkist, Redskin, and Loring] were punctured at 31, 33, and 38 days after full bloom (DAFB), respectively. Injections of water, $390 \mathrm{mg} \mathrm{GA}_{3} /$ liter, or $390 \mathrm{mg} \mathrm{GA} \mathrm{A}_{47} /$ liter were made immediately following seed puncture. Seed puncture and water injection following puncture resulted in abscission of all fruit. Injection of $\mathbf{G A}_{3}$ and $\mathbf{G A}_{4+7}$ delayed abscission of 'Redkist' and 'Redskin' fruits of punctured seeds by 6 to 10 days. Both GA treatments resulted in normal growth into Stage II and increased fruit retention through Stage III in 'Loring'. About $100 \mu \mathrm{l}$ of 250,500 , or $1000 \mathrm{mg} \mathrm{GA}_{3} /$ liter was injected into the locule of 'Loring' fruits following seed puncture at 30, 40, or 50 DAFB. GA treatments at 30 DAFB resulted in $\approx 75 \%$ fruit set in comparison to seeded control fruit, while fruit treated at 40 and 50 DAFB abscised by the end of Stage II. Increasing GA concentration from 250 to $1000 \mathrm{mg} \cdot \mathrm{liter}^{-1}$ had no additional effect. Movement of the GA was examined by injecting ${ }^{3} \mathrm{H}-\mathrm{GA}_{1}$ into the locule following the puncture treatment. More than $97 \%$ remained in the fruit after 96 hours. The percentage of ${ }^{3} \mathrm{H}$ recovered in the seed cavity decreased over time, whereas recovered label increased in both endocarp and mesocarp. The results suggest a potential regulatory role for seed-produced gibberellins during early Stage $I$ of development. We have identified an apparent change in tissue sensitivity to gibberellin induction of seedless fruit development between 30 and 40 DAFB in 'Loring' peach.
\end{abstract}

Peach fruit development is recognized to have three stages of development (Connors, 1919). Stage I is characterized by rapid growth of the pericarp and limited embryonic development, Stage

Received for publication 26 Apr. 1988. Scientific Article no. A-4792. Contribution no. 7813 of the Maryland Agricultural Experiment Station, College Park. We thank the Fruit Laboratory, USDA, Beltsville, Md., for the use of plant material and Chic Nishijima, Dept. of Pomology, Univ. of California, Davis, for the gift of ${ }^{3} \mathrm{H}-(3,4)$ gibberellin $\mathrm{A}_{1}$. The cost of publishing this paper was defrayed in part by the payment of page charges. Under postal regulations, this paper therefore must be hereby marked advertisement solely to indicate this fact.
II by rapid development of the embryo and hardening of the endocarp, and Stage III by rapid mesocarp expansion (final swell). Cultivars differ in the length of each phase, with early and lateseason cultivars differing chiefly in the duration of Stage II (Tukey, 1936). Extensive physiological, biochemical, and morphological changes occur during early seed development (Stage I) (Thorne, 1985; Zucconi, 1983). The role of growth substances in fruit set and development of peach has been reviewed by, among others, Nitsch (1953), Powell and Pratt (1966), Luckwill et al. (1969), Crane (1969), and Zucconi (1983).

Small, parthenocarpic fruit generally abscise by late Stage I 
(Crane, 1963). Abscission of some fruit ("June drop") occurs at the onset of Stage II. Tukey (1936) found that killing the embryo during early Stage II, but not during late Stage II or Stage III, caused fruit abscission of several peach and cherry cultivars. He concluded that fruit set and development are dependent on a viable ovule.

Parthenocarpic peaches can be induced to set and develop if sprays of $\mathrm{GA}_{3}>250 \mathrm{ppm}$ are applied from $50 \%$ full bloom to 7 days after full bloom (DAFB)(Crane, 1963). Stutte (1985) found a $15 \%$ increase in fruit set over seeded fruit when $\mathrm{GA}_{3}$ was injected into the ovule following embryo abortion 23 DAFB in 'Biscoe' peach.

We sought to further examine the role of the seed in early peach fruit development. We hypothesized that gibberellins will substitute for a Stage I seed and permit normal fruit set and development. Our objectives were to test the effect of time of GA application and concentration, the response of cultivars to GA under orchard conditions, and determine the movement of GA following application.

\section{Materials and Methods}

Seed abortion. Six-year-old trees of the mid- to late-season 'Loring', 'Redskin', and 'Redkist' peaches growing in the orchards of the USDA/ARS, Beltsville, Md., were used in these experiments in 1986. A randomized block design consisting of three replicates of five trees per replicate was used for each cultivar, for a total of 15 trees per cultivar. Uniform branches (> $3 \mathrm{~cm}$ at basal end) around each tree were selected for each treatment, and fruits were thinned to three per shoot; the middle fruit on each shoot was tagged for treatment. Five treatments were applied on 8 May 1986, a date that corresponded to 31 DAFB for 'Redskin', 33 DAFB for 'Redkist', and 38 DAFB for 'Loring'. The treatments were a seeded control, seed puncture, and seed puncture with injection of $\mathrm{GA}_{3}$ or $\mathrm{GA}_{4+7}$, both at $390 \mathrm{mg} \cdot \mathrm{liter}^{-1}$ or of water $(100 \mu \mathrm{l} \mathrm{each})$. Each treatment was repeated three times on each tree for a total of 45 sample fruit per treatment.

The injections were made with a $1.27-\mathrm{cm} 25$-gauge needle. The seed coat was ruptured by an initial puncture made through the basal end into the locule, while injection of $100 \mu \mathrm{l}$ of GA or water was made at the apical end with a second puncture into the locule. The initial puncture reduced pressure build-up associated with the injections and acted as a channel of escape for the 50 to $100 \mu \mathrm{l}$ of liquid endosperm that was forced from the endocarp by the injection. It is assumed that the $100 \mu \mathrm{l}$ of GA was injected into the locule. Vernier calipers were used to measure the cheek diameter of all non-abscising fruit every 3 days through Stage II, and weekly thereafter. The date of abscission of each tagged fruit was recorded.

Experiments were conducted in 1987 at the Wye Research and Education Center, Queenstown, Md. on 4-year-old 'Loring' peach trees. To determine the effect of timing and GA concentration effects, fruit were injected at 30,40 , or 50 DAFB with $100 \mu \mathrm{l}$ of $0,250,500$ or $1000 \mathrm{mg} \mathrm{GA}_{3} /$ liter, as described above. Additional untreated (seeded) branches were tagged and left as controls. Four single-tree replicates in a randomized block design were used for each timing treatment, for a total of 12 trees. Concentration treatments were applied to all the fruit on a branch (basal diameter $>3 \mathrm{~cm}$ ), using a minimum of 50 fruit per branch. All concentrations were applied to each tree, for a total of four branches per concentration per date. The percentage of fruit retained on a branch was determined at the end of Stage II (64
DAFB). Regression analysis was performed following $\log (\mathrm{x}-1)$ transformation of the percent set data.

Transport of ${ }^{3} \mathrm{H}-(3,4)$ gibberellin $A_{l}$. At 38 DAFB, fruiting shoots of 'Loring' were excised and brought into the laboratory and the bases were recut and placed into water. About $0.5 \mu \mathrm{Ci}$ of ${ }^{3} \mathrm{H}-(3,4)$ gibberellin $\mathrm{A}_{1}\left(30 \mathrm{Ci} \cdot \mathrm{mmol}^{-1} ; 1 \mathrm{Ci}=37 \mathrm{GBq}\right)$ was injected into the fruit following the puncturing of the embryo, as described above. $\mathrm{GA}_{1}$ was chosen as the tracer because it is the active gibberellin in various model systems (MacMillan and Phinney, 1987). A single fruit was removed from each of three single-shoot replicates at 48 and $96 \mathrm{hr}$ and separated into seed, pericarp, petiole, and stem tissues. To minimize crosscontamination of tissue samples with ${ }^{3} \mathrm{H}$ during excision, the tissue at the point of injection was discarded and the scalpel rinsed three times in $100 \%$ methanol before excising a different tissue.

Tissues were homogenized in $80 \%$ methanol $(\mathrm{MeOH})$ using a mortar and pestle and centrifuged at $17,000 \times g$ for $20 \mathrm{~min}$, and the supernatant saved. The pellet was resuspended two more times in $80 \% \mathrm{MeOH}$, then centrifuged, and the supernatants were combined. The remaining pellet was resuspended in a scintillation vial with a minimal volume of $100 \%$ methanol. After the samples were taken to dryness a centrifugal rotary evaporator (Savant Speed-Vac, Farmingdale, N.J.), 10-ml scintillation cocktail (PCS, Amersham, Arlington Heights, Ill.) was added, and then the samples were counted in an Intertechnique SL30 scintillation counter. Quench correction was obtained using the external standard method.

\section{Results}

Seed abortion. All puncture and injection treatments resulted in fruit abscission of 'Redskin' and 'Redkist' by the end of Stage II (Fig. 1 a and b). Injection of water had little effect, whereas both GA treatments delayed the onset of abscission by several days. In 'Loring', fruit abscission was not affected by injection of water, but both GA treatments inhibited fruit abscission through Stage I; $68 \%$ of the $\mathrm{GA}_{3}$-treated and $42 \%$ of the $\mathrm{GA}_{4+7}$-treated fruit being retained 5 weeks after treatment.

Although not obvious from Figs. 1 or 2, a decrease in growth rate of 'Loring' fruit was observed within 4 days of seed puncture unless GA was injected. Periodic sectioning of a population of seeded fruit indicated that the decline in rate of growth in non-abscising fruits corresponded to the onset of Stage II (Fig. 2). Abscission of fruit was unrelated to initial fruit size. Thirtyseven percent of the GA-treated fruits developed to maturity and ripened $\approx: 2$ weeks before seeded controls. These fruits appeared slightly elongated during Stage I and Stage II, but were similar in shape to seeded fruit at harvest.

$\mathrm{GA}_{3}$ partially counteracted the effect of seed puncture on abscission when injected at 30 DAFB (Fig. 3). By the end of Stage II (64 DAFB), all the embryo-aborted fruit not treated with GA had abscised, irrespective of treatment date. Gibberellin application at 30 DAFB resulted in $\approx 75 \%$ fruit retention, relative to seeded controls. The GA injections at 40 and 50 DAFB (onset and middle of Stage II) delayed the onset of fruit abscission, but $95 \%$ of the fruit abscised 14 days after treatment; no fruit treated at 40 or 50 DAFB reached maturity.

Transport of ${ }^{3} \mathrm{H}$ - $(3,4)$ gibberellin $A_{1}$. After $48 \mathrm{hr}, 79 \%$ of the ${ }^{3} \mathrm{H}$-activity injected was recovered from seed tissue and $19 \%$ from pericarp. After $96 \mathrm{hr}$, these values were $56 \%$ and $41 \%$, respectively. No more than $3 \%$ of activity was recovered outside the fruit at either time. More than $90 \%$ of the ${ }^{3} \mathrm{H}$ activity was detected in the $\mathrm{MeOH}$-soluble fraction at both 48 and $96 \mathrm{hr}$. 

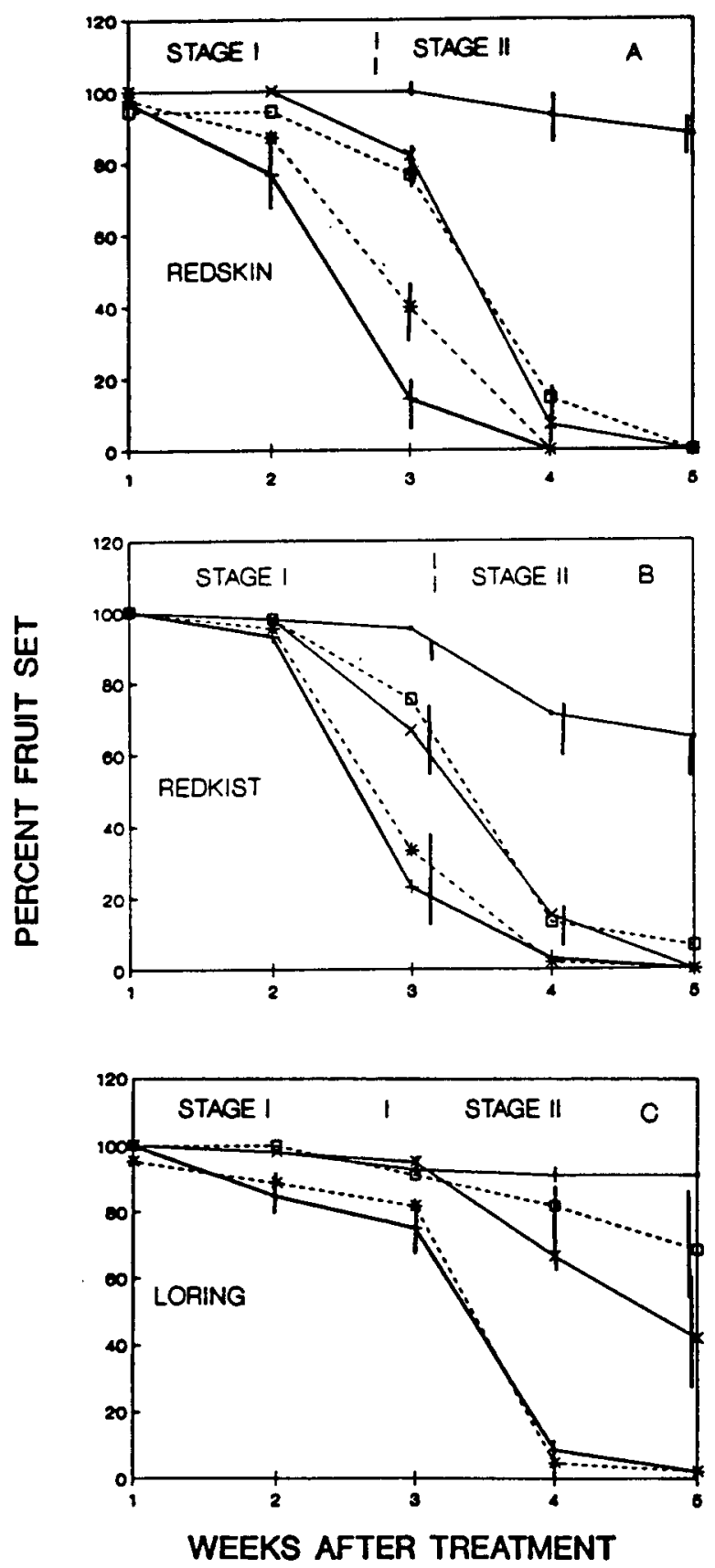

Fig. 1. Fruit retention of seeded $(\bullet-)$ fruit, seed puncture $(+)$ fruit and fruit injected with water (--*--), $390 \mathrm{mg} \mathrm{GA} / 1$ iter (-- $\square--)$ or $390 \mathrm{mg} \mathrm{GA}{ }_{4+7} /$ liter in (_*-) (A) 'Redkist', (B) 'Redskin', and (C) 'Loring' peach. Each point represents mean of three replicates of 15 fruit per replicate ( \pm SE).

\section{Discussion}

A viable seed must be present throughout Stage I if the peach fruit is to mature normally. Tukey (1936) showed that the seed is also required during early Stage II of development for subsequent fruit maturation. No such requirement exists in late Stage II. Crane (1963) showed that GA sprays up to petal fall resulted in development and maturation of parthenocarpic fruit. Our experiments have characterized the effect of GA injection directly into the locule on development of peach fruit following seed abortion during mid to late Stage I. At least two periods

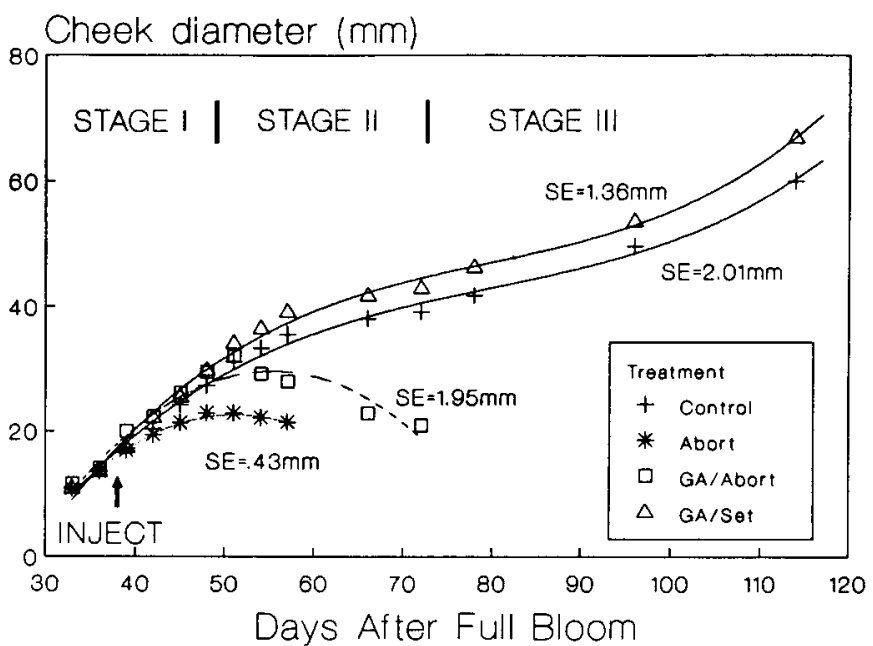

Fig. 2. Growth of seeded, seed-punctured, and gibberellin-injected 'Loring' peach fruit. Control [set $=-75.6+3.84 *$ (DAFB) $\left.0.045 *(\mathrm{DAFB})^{2}+0.0002 *(\mathrm{DAFB})^{3} ; r^{2}=0.970\right]$ represents mean of seeded fruit $(\mathrm{N}=45)$ at each concentration. Abort [set $=-75.7$ $\left.+3.84 *(\mathrm{DAFB})-0.038 *(\mathrm{DAFB})^{2} ; r^{2}=0.993\right]$ represents mean of seed-punctured and water-injected fruit $(\mathrm{N}=90)$. Data for $\mathrm{GA}_{3}$ and $\mathrm{GA}_{4+7}-$ injected fruit $(\mathrm{N}=89)$ were combined and $\mathrm{GA} /$ Set [set $=-95.4+4.76 *(\mathrm{DAFB})-0.056 *(\mathrm{DAFB})^{2}+0.0002 *(\mathrm{DAFB})^{3} ;$ $\left.r^{2}=0.994\right]$ represents all fruit that had not abscised at 115 DAFB $(\mathrm{N}=23)$ and GA/Abort [set $=-88.5+4.27 *(\mathrm{DAFB})-$ $0.038 *(\mathrm{DAFB})^{2} ; r^{2}=0.929$ ] all fruit that had abscised $(\mathrm{N}=66)$. Fruit diameters of abscised fruit were excluded from growth measurements.

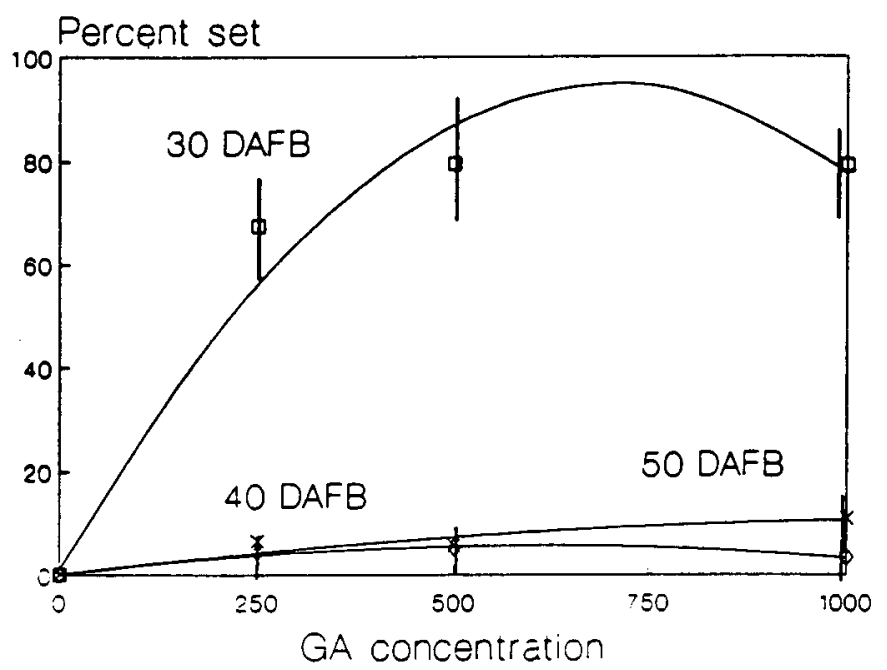

Fig. 3. Effect of timing and concentration of $\mathrm{GA}_{3}$ injection into the locule of 'Loring' peach on fruit set at end of Stage II (64 DAFB). $A$ quadratic equation was fit to concentrations for each treatment time. [Set at $30 \mathrm{DAFB}=1.02+0.27 *(\mathrm{GA})-0.0002 *[\mathrm{GA}]^{2}, r^{2}$ $=0.98$; Set at $40 \mathrm{DAFB}=0.21+0.018 *(\mathrm{GA})-8 \times 10^{-6} *(\mathrm{GA})^{2}$, $r^{2}=0.928$; set at $50 \mathrm{DAFB}=0.043+0.019 *(\mathrm{GA})-1.6 \times$ $\left.10^{-5}(\mathrm{GA})^{2}, r^{2}=0.98\right]$. Data points represent mean of three replicates $\pm \mathrm{SE}$.

exist during Stage I of 'Loring' that differ in their qualitative response to GA. Before 40 DAFB, application of GA resulted in fruit retention and development through Stage III. After 40 DAFB, GA application permitted development through Stage I, 
but not through Stages II and III. In 'Redskin' and 'Redkist', GA injection in mid-Stage I (31 and 33 DAFB, respectively) permitted fruit growth through Stage I, but not Stages II and III.

Abscission of fruit following seed-abortion does not occur for about 2 weeks, although fruit growth rate declines within 4 to 7 days. Presumably, redistribution of nutrients and abscission zone formation occur during this time. Cessation of growth and decreasing cheek diameter (mummification), without immediate abscission, explains the apparent decline in growth of 'Loring' fruit during Stage II. In contrast, fruit size of all three cultivars continued to increase following injection of GA. The increase persisted for only 6 to 10 days in 'Redskin' and 'Redkist' before growth ceased and fruit abscission began, but it continued throughout Stage I in 'Loring'. These results indicate that gibberellin, either directly or indirectly, enhances sink strength of the fruit. Delayed abscission following GA treatment was not affected by cultivar, timing, type of gibberellin or concentration (over the range tested) (Fig. 1).

'Loring' fruit development following seed abortion was affected by timing of GA injections. When $\mathrm{GA}_{3}$ was injected directly into the ovule at $30 \mathrm{DAFB}$, fruit growth rate was increased, abscission of fruit through Stage II was substantially reduced, and $25 \%$ of the fruit with aborted seeds developed to maturity. When $\mathrm{GA}_{3}$ was injected at 40 DAFB, abscission was delayed but development of seed-aborted fruit to maturity no longer resulted. A concentration of $1000 \mathrm{mg} \mathrm{GA}_{3} /$ liter was no more effective than $250 \mathrm{mg} \cdot$ liter $^{-1}$ in affecting fruit growth or abscission at any treatment date. Tissue sensitivity to GA induction of fruit development in seed-aborted fruit is apparently lost during late Stage I of peach growth.

Although phytohormones are present in developing seeds of peach (Jackson, 1968; Crane, 1969), their role in fruit growth is not well-understood. Whether de novo synthesis is occurring in the embryo, as is often assumed, or in the endosperm tissue is also unknown. Thorne (1985) reviews transport into developing seeds; however, no clear understanding exists of how the transport of phytohormones from the seed occurs and how they might regulate fruit development. The endosperm is enclosed within the testa, which is impermeable (Zucconi, 1983). In preliminary experiments, we did not observe any movement of neutral red, Congo red, or eosin Y from the locule into the adjoining endocarp after $72 \mathrm{hr}$ of direct contact (data not presented).
From the ${ }^{3} \mathrm{H}-\mathrm{GA}_{1}$ studies, label clearly moved out of the locule into the pericarp tissue in the $\mathrm{MeOH}$-soluble fraction. At the very least, this indicates that the ${ }^{3} \mathrm{H}$ is able to move into other tissues from the seed cavity. Although precautions were taken to exclude the puncture wound from each sample, the treatment technique disrupted natural barriers to transport from the seed, thus precluding definitive interpretation of the results.

These results clearly demonstrate that GA can replace the seed in 'Loring' through mid-Stage I, but not later. In 'Redkist' and 'Redskin' mid-Stage I application of GA partially substitutes for the seed. It is concluded that other hormones associated with the seed must be involved in fruit growth from mid-Stage I to mid-Stage II.

\section{Literature Cited}

Connors, C.H. 1919. Growth of fruits of the peach. New Jersey Agr. Expt. Sta. Annu. Rpt. 40:82-88.

Crane, J.C. 1963. Parthenocarpic peach development as influenced by time of gibberellin application. Proc. Amer. Soc. Hort. Sci. 83:240247.

Crane, J.C. 1969. The role of hormones in fruit set and development. HortScience 4:8-11.

Jackson, D.I. 1968. Gibberellin and the growth of peach and apricot fruits. Austral. J. Biol. Sci. 21:209-215.

Luckwill, L.C., P. Weaver, and J. MacMillan. 1969. Gibberellins and other growth hormones in apple seeds. J. Hort. Sci. 44:413-424.

MacMillan, J. and B.O. Phinney. 1987. Biochemical genetics and the regulation of stem elongation by gibberellins, p. 156-171. In: D.J. Cosgrove and D.P. Knievel (eds.). Physiology of cell expansion during plant growth. Amer. Soc. Plant Physiol. Rockville, Md.

Nitsch, J.P. 1953. The physiology of fruit growth. Annu. Rev. Plant Physiol. 4:199-236.

Powell, L.E. and C. Pratt. 1966. Growth promoting substances in the developing fruit of peach (Prunus persica L.). J. Hort. Sci. 41:331348.

Stutte, G.W. 1985. Effect of seed destruction on fruit set and development in peach. HortScience 21:184. (Abstr.)

Thorne, T. 1985. Phloem unloading of $\mathrm{C}$ and $\mathrm{N}$ assimilates in developing seeds. Annu. Rev. Plant Physiol. 36:317-343.

Tukey, H.B. 1936. Development of cherry and peach fruits as affected by destruction of the embryo. Bot. Gaz. 98:1-24.

Zucconi, F. 1983. Peach, p. 303-332. In: S.P. Monselise (ed.). Handbook of fruit set and development. CRC Press, Boca Raton, Fla. 